\title{
The Relationship of Sustainability Communication on Social Media with Banking Consumers' Loyalty through e-WOM
}

\author{
Gao Wei ${ }^{1,2}$, Wang Lin $^{3}$, Wu Yanxiong ${ }^{4, *(\mathbb{D}}$, Yan Jingdong ${ }^{1, *}$ and Sadik Yusuf Musse ${ }^{5}$ \\ 1 School of Management, Wuhan University of Technology, Wuhan 430000, China; hkxygj_edu@sina.com \\ International Exchange College, Hankou University, Wuhan 430212, China \\ Admission Unit, Hankou University, Wuhan 430212, China; lynmissing@sina.com \\ Jiyang College Zhejiang A\&F University, Zhuji 311800, China \\ 5 School of Medicine, Wuhan University, Wuhan 430071, China; qabiile@hotmail.com \\ * Correspondence: 13601213097@163.com (W.Y.); yjdong02@163.com (Y.J.)
}

Citation: Wei, G.; Lin, W.; Yanxiong, W.; Jingdong, Y.; Musse, S.Y. The Relationship of Sustainability

Communication on Social Media with Banking Consumers' Loyalty through e-WOM. Sustainability 2021, 13, 3832. https://doi.org/10.3390/su13073832

Academic Editor:

Manuel Rodríguez-Díaz

Received: 28 February 2021

Accepted: 17 March 2021

Published: 31 March 2021

Publisher's Note: MDPI stays neutral with regard to jurisdictional claims in published maps and institutional affiliations.

Copyright: () 2021 by the authors. Licensee MDPI, Basel, Switzerland. This article is an open access article distributed under the terms and conditions of the Creative Commons Attribution (CC BY) license (https:// creativecommons.org/licenses/by/ $4.0 /)$.

\begin{abstract}
Prior literature has largely addressed corporate social responsibility (CSR) from outcomes related to organizational themes. However, its importance for achieving consumer-related outcomes is something that has been largely ignored by contemporary researchers. Likewise, how CSR communication through social media can create positive emotions on the part of consumers has to date been under-explored. Hence, the present study aims to fill these gaps by investigating the impact of CSR communication of an organization through social media on consumer loyalty. The study also proposes electronic word of mouth (e-WOM) as a potential mediator between this relationship. The proposed model of the present study was tested in the banking sector of a developing country. The data were collected from a self-administered questionnaire and analyzed through the structural equation modeling technique (SEM). The results of the present study validated that CSR communication of a bank through social media directly and indirectly, through e-WOM, influences consumer loyalty in a positive manner. The results of the present study will be helpful for policymakers to better understand how well-planned CSR communication of an organization on social media can lead towards better consumer-related outcomes such as consumer loyalty and e-WOM.
\end{abstract}

Keywords: sustainability; social media; corporate social responsibility; positive emotion; e-WOM

\section{Introduction}

Social media has emerged as a new communication medium in the present era of digitalization. This new media has influenced every business sector and perhaps this is the reason that today the majority of the organizations recognize the importance of social media to communicate with different stakeholders including consumers [1]. Presently, more than 3.8 billion individuals around the world are using social media [2] with an increase of $10.9 \%$ per year [3]. These statistics clearly highlight the importance and popularity of social media for contemporary businesses as a new model of business communication [4]. Perhaps this is the reason that many global brands like Nike, Spotify, Dove, Bosch, Starbucks, and Wendy's have their active presence on different social media platforms. These brands not only communicate with different stakeholders on social media but also engage their stakeholders with the brand in a meaningful way [5]. Unlike, conventional media, social media is flexible and interactive in its nature. This interactive environment along with flexibility in communication are two of the major strengths of social media explaining why they have gained a significant popularity in comparison to conventional media [6].

Hence, the emergence of social media is a new dawn in the field of organizational communication [4].

Perhaps the concept of corporate social responsibility (CSR) is as old as the business itself. There have been different examples of CSR in the history of the ancient world from the perspective of wellbeing [7]. As a result of industrialization in Europe and other parts of the 
world, many large enterprises came into existence. With this industrialization, the debate on the social responsibility of business also started and, hence, the first book on CSR with the title "social responsibility of the businessman" appeared in 1953 by BowenandJohnson [8]. Since then, to date, the concept of CSR has been in discussion among policymakers and academicians. Contemporary businesses practice CSR activities in order to address the pressure from different stakeholders including consumers, competitors, governments, and others. These stakeholders expect businesses to be engaged in sustainability practices in order to preserve society and the environment at large [9]. Businesses in the present era of digital communication use social media to communicate their CSR activities with different stakeholders in order to let them know the organization's positive contribution to society and the environment [10]. There are different studies in the extant literature of CSR that highlighted the importance of social media for effective CSR communication with stakeholders [11-13].

The discussion of CSR has gained a lot of momentum in contemporary literature during the last two decades. But its boundaries are ever-evolving even in 2021 [14,15]. Prior literature has largely examined CSR to achieve different organizational-related outcomes such as organizational performance [16], quality management [17], and organizational commitment [18]. Likewise, contemporary CSR researchers have also investigated CSR from the perspective of employees, for example, in their study Gao and He [19] noted a positive relationship between CSR and employees' organizational citizenship behavior and Kong, et al. [20], acknowledged CSR as an important factor to shape the pro-environmental behavior of employees. However, recent literature has largely ignored how the phenomenon of CSR can be used to achieve consumer-related outcomes such as word of mouth (WOM) and consumer loyalty. There have been some studies examining the concept of CSR to induce WOM $[21,22]$ and consumer loyalty $[12,23,24]$ but these are inconclusive. Further, it is not clear from the existing studies how CSR can be used to create a positive brand attitude (WOM) for a specific organization or brand. Hence the aim of the present study is to investigate the impact of CSR activities of an organization through social media on consumer outcomes such as consumer loyalty and WOM. In this regard, the present study proposes that CSR communications of an organization through social media have a positive impact on consumer loyalty and electronic WOM mediates this relationship.

The proposed model of the present study was tested in the banking sector of China. The researchers have selected this sector due to two important reasons. First, the banking sector is labeled as a homogenized sector in which almost all banks are operating under the same standard procedures with very little product/service differentiation. This process of standardization makes it almost impossible for a bank to differentiate its product or services from the competitors in order to convince its consumers and to earn their loyalty [12]. The present study argues that effective CSR communication on social media can provide a bank with an extra edge to convince their consumers that a particular bank is well-differentiated from the competitors due to its socially responsible attitude. It is worth mentioning here that modern consumers are very concerned with the eco-friendly practices of all businesses and they prefer to purchase from a socially responsible organization [25]. Second, the banking industry of China is very competitive in the present era of digitalization. This stiff competitive environment makes it challenging for every bank to hold its consumers because holding consumers in a tough industry is very difficult [26]. The present study here argues that well-planned CSR communication of a bank on social media enables a bank to shape the behavior of their consumers positively. Consumers appreciate the CSR initiatives of their bank and become loyal to them. Consumer loyalty will remain a very important business preference for every sector due to the fact that loyal consumers are less likely to consider the competing brands [27].

The present study adds significantly to the existing literature. First, the present study adds to the existing literature of CSR from the perspective of consumer and behavior (loyalty and WOM). This is very important to mention here that the positive brand attitude of consumers is very important for every organization. There have been different studies 
that acknowledged that a positive consumer attitude is helpful in shaping their behavior positively [28]. However, contemporary researchers have failed to address how CSR-related communication on social media can shape the attitudinal and behavioral preferences of consumers for a specific brand. It is worth mentioning here that positive brand attitude such as using positive WOM for a brand, is a key touch-point for marketers to shape consumer behavior such as their level of loyalty [29]. Second, the present study enriches the existing literature of CSR by proposing electronic word of mouth (e-WOM) as a mediating variable between CSR communication on social media and consumer loyalty. The logic for introducing e-WOM as a mediating variable lies in the argument that CSR-related communication of an organization on social media creates positive emotions among consumers. The consumers in response, are expected to use positive words (e-WOM) with their social media peers and colleagues [30], which induces their loyalty in a positive manner. Lastly, the present study is a pioneer to present the blend of CSR and social media for a meaningful consumer brand journey. The study contends that through CSR communication on social media, an organization is able to engage their consumers meaningfully as they interactively communicate with their consumers. Hence, the availability of social media provides an interactive communication medium through which, the consumers have their voice and say for a specific brand. The above arguments clearly highlight the existence of gaps in the literature and the importance of conducting this study.

\section{Theory and Hypotheses}

The present study uses attribution theory and the theory of norm reciprocity as the grounding theories. The attribution theory was proposed by Fritz [31] and the theory of norm reciprocity was proposed by Gouldner [32]. Both these theories have been heavily used in studies related to consumer behavior. Attribution theory is helpful in understanding the reasons for individual behaviors for different events. Many researchers have used attribution theory in the field of consumer behavior [33-35]. In the context of the present study, the attribution process is helpful for consumers in the identification of a brand or an organization as a socially responsible one. Furthermore, the process of attribution also helps consumers in brand evaluation. The theory of norm reciprocity by Gouldner [32] states, when individuals receive some sort of benefit from others, it is likely that they want to reciprocate this benefit positively. In this regard, when consumers perceive an organization as a socially responsible organization, they feel positive about that organization and want to reciprocate it positively.

WOM is very important in the field of marketing due to the reason that consumers trust the comments about a product or brand given by other consumers. According to a study conducted by Nielsen [36], more than $90 \%$ of the consumers believe that recommendations or suggestions from other consumers, family members, or friends are more valuable as compared to advertising. Hence, the importance of WOM is without any doubt. The rise of social media further adds to the importance of WOM because it provides an interactive medium through which consumers exchange their product-related views with their social media peers [37].

As per the definition of word of mouth (WOM), it is an informal communication process actuated by consumers with other consumers [38]. In this process, the consumers discuss proprietorship, product utilization experience, and product quality of a specific brand or organization [39]. Sometimes, WOM is regarded as a referral, but it is only one facet. Referrals pave the way to the form of direct and indirect exhortation by summing up what the consumers say to other consumers [40]. However, WOM has been found to incorporate more than just recommendations. People quote from their experiences of what has happened in the past in terms of a product experience [41]. WOM can be quoted as a dominant origin of knowledge for individuals talking to others. For instance, consumers keep in consideration the phenomenon of WOM when making purchase decisions [42]. Although the comparative influence of sentiment in e-WOM is still blurred, it is logical to assume that the high predominance of sentiments prompted on websites and interactive 
channels lead to higher sentimental e-WOM created by the online communities [43]. Sentiments are interconnected from a psychological phenomenon to the notion that can be conceptualized as a perceived physical/mental sensation.

The technology-based revolution has provided an opportunity for marketers to effectively utilize e-WOM to attain different marketing-related objectives [44]. Bellman, et al. [45], mentioned that online product information search plays an important role in online buying behavior. The information obtaining and offering behavior is essential to digital markets [46]. Demirbas [47] scrutinized the constructive influence of e-WOM features and elements on e-commerce business. However, because of strong rivalry in the present era of digitalization, the consumers are immersed in information, brand indicators, and advertising memorandum, both offline and online [48].

Organizations participate in CSR activities in order to develop a positive attitude of the consumers towards the organization and to build their positive image [49]. Incorporating a CSR program increases an organization's visibility, and encourages more communication with consumers. Therefore, it is expected that an organization's engagement in CSR activities is likely to induce positive WOM on the part of consumers [50]. Consumers are concerned about the quality of service provided by the enterprise, in terms of social responsibilities. CSR engagement of an organization builds a positive image of the organization [51] and hence they are urged to stay connected with the organization. Through the halo effect, the positive image of an organization created by CSR activities leads consumers to develop a better perception of the organization. This well-rounded perception of the organization attracts consumers to the organization's products and services [52]. As a result, consumers often speak positively about a company which is engaged in CSR initiatives, as well as also associating themselves positively with the products and services of the organization. When consumers observe an organization practicing CSR programs actively, they build a positive attitude towards that organization and communicate positively, hence they spread positive WOM for the organization [53].

In the context of attribution theory [31], CSR engagement of an organization through social media helps consumers in evaluating and labeling a particular organization as socially responsible. In this regard, they seek support from the attribution process and evaluate an organization or brand positively. Likewise, in line with the theory of norm reciprocity [32], the CSR activities of an organization urge consumers to develop positive emotions for that organization. Hence, they are expected to reciprocate that organization positively to acknowledge its positive contribution towards society and the environment. In a nutshell, the present study argues that CSR communication of an organization on social media urges consumers to use positive e-WOM for that organization with other social media peers. When other social media peers receive such positive evaluations from their online peers, they feel positive for that organization and wish to stay with it for as long as they can. This process eventually is translated into a higher level of loyalty. Therefore, the following set of the hypothesis is proposed along with the research model (Figure 1) of the present study.

Hypothesis 1 (H1). CSR communications of an organization on social media are positively related to consumer loyalty.

Hypothesis $\mathbf{2}$ (H2). CSR communications of an organization on social media are positively related to $e-W O M$.

Hypothesis 3 (H3). e-WOM mediates between CSR communications on social media and consumer loyalty. 


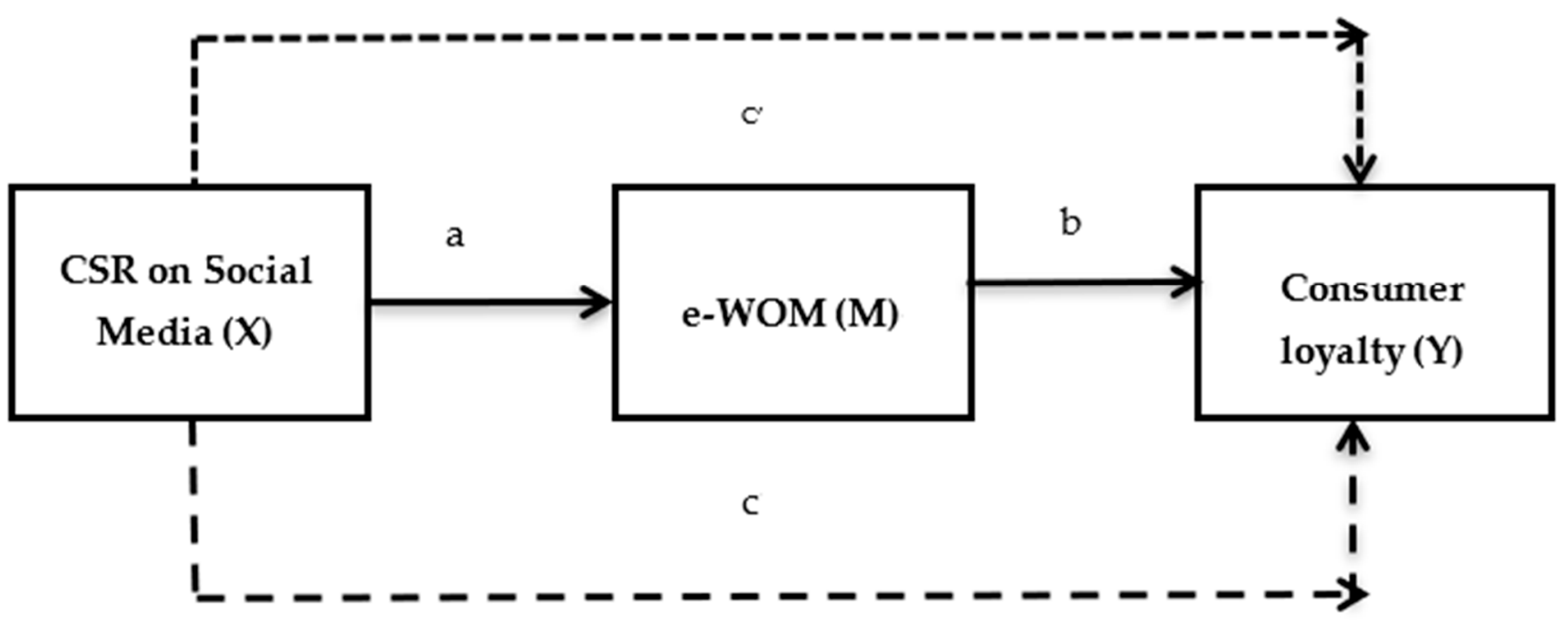

Figure 1. Proposed research model: Based on authors' conception of corporate social responsibility (CSR) on social media $(\mathrm{X})=$ the independent variable, consumer loyalty $(\mathrm{Y})=$ the dependent variable, electronic word of mouth $(\mathrm{e}-\mathrm{WOM})(\mathrm{M})$ $=$ the mediating variable, $\mathrm{c}=$ direct effect of $\mathrm{X}$ on $\mathrm{Y}$ without the effect of the mediator, $\mathrm{c}^{\prime}=$ indirect effect of $\mathrm{X}$ on $\mathrm{Y}$ with mediator, $\mathrm{a}=$ the direct impact of CSR on social media on e-WOM, $\mathrm{b}=$ direct impact of e-WOM on consumer loyalty.

\section{Methodology}

The proposed model of the present study was tested in the commercial banking sector of China. There are 12 commercial banks in China nationwide having multiple branches all over the country. The authors selected three major banks to represent the banking sector of china including China Merchants Bank, Industrial Bank, China CITIC Bank. There were two reasons for choosing these banks for data collection, first, these banks are the largest commercial banks in China and having their presence all over the country. Second, these banks were actively involved in CSR activities and communication of such activities on different social media platforms. Hence in the perspective of the present study, the selection of these banks seems logical. The data were collected from the individuals who had a bank account in one of these banks in the city of Wuhan of Hubei province, which is one of the largest cities in China.

Before actuating the data collection phase, the authors received the informed consent of the respondents to voluntarily participate in the survey. Furthermore, the respondents were told that the secrecy of their data will be highly maintained and will not be shared with anyone. The authors distributed 1000 questionnaires among different respondents and finally received 491 fully filled questionnaires which were used in data analysis. Hence, the response rate of the present study remained around $49.1 \%$. The data collection process almost took one month (15 November-15 December 2020)

\section{Measures and Handling of Social Desirability}

The authors used pre-existing scales for measuring the variables of the present study. Hence, the reliability and validity of the instrument were pre-established. In this regard, 
the authors adapted the scale of CSR from the studies of van Asperen, et al. [54] and Eisingerich, et al. [55], this scale comprised five items. The scale of e-WOM was adapted from the study of Kangand Hustvedt [56], this scale consisted of three items. Finally, a three-item scale of consumer loyalty was adapted from [57]. All the items were rated on a five-point Likert scale. All items have been reported in Appendix A.

Next, the authors addressed the issue of social desirability. In this regard, the authors took several steps to mitigate the effect of social desirability. For example, the authors scattered all items of the variables in the questionnaire randomly. This strategy is helpful to break any intended sequence on the part of the respondents in answering the questions. Furthermore, this strategy is also helpful to address any liking or disliking of the respondent(s) for a variable. The use of this strategy to mitigate social desirability is also recommended by extant researchers $[15,20,58]$. Likewise, the instrument was crosschecked by the experts from academia in order to detect any ambiguity or complexity in questionnaire items. Lastly, the authors cleared the respondent about the importance of their true response in generating the results of the present study. Hence, through these steps, the potential issue of social desirability was mitigated to the best possible limit. The demographic profile of the respondents is presented in Table 1.

Table 1. Demographic information of the respondents.

\begin{tabular}{ccc}
\hline Demographic & Frequency & $\%$ \\
\hline Gender & & \\
\hline Male & 281 & 57.23 \\
Female & 210 & 42.77 \\
\hline Age & & \\
\hline $18-25$ & 83 & 16.90 \\
$26-30$ & 164 & 33.40 \\
$31-40$ & 182 & 37.07 \\
Above 40 & 62 & 12.63 \\
\hline Education & & \\
\hline Intermediate & 88 & 17.92 \\
Graduate & 157 & 35.98 \\
Master & 172 & 15.07 \\
Higher & 74 & $\mathbf{1 0 0}$ \\
\hline Total & $\mathbf{4 9 1}$ & \\
\hline
\end{tabular}

\section{Results}

\subsection{Common Method Variance, Validity and Reliability}

In the data analysis phase, the authors, first of all, tested for common method variance (CMV). The authors were interested to check the potential issue of CMV in the dataset of the present study because the data for all variables were collected from the same individual. Hence, there is the possibility that there may be the presence of CMV in the collected data. In order to know whether the issue of CMV exists, the authors performed a single factor analysis [59]. In this regard, the authors loaded all the items of the survey onto a single factor using SPSS software. The rule of thumb here is that, if the results of Harman single factor analysis indicate that there is the presence of a single dominant factor which is explaining more than $50 \%$ of the total variance, it confirms the presence of CMV. In the case of the present study, the authors observed no such factor explaining this much variance. In this connection, the maximum variance explained by a single factor was $39.71 \%$ which is less than the threshold level of $50 \%$. Hence, the authors established that the potential threat of CMV is absent.

The next phase in the data analysis was to perform exploratory factor analysis in order to detect if there are some items with weak or cross-loadings. In doing so, the authors performed principal component analysis (PCA) using varimax rotation in SPSS. The results 
produced satisfactory results as there was no item with cross-loading or weak loading and all items had factor loading greater than 0.5 [60]. Table 2 presents different results including the results of correlation analysis, validity and reliability analyses, normality test, and the factor loadings. According to Table 2, the values of correlation amongst all variables are positive and significant which means that the variables of the present study are positively related to each other.

Table 2. Correlations, validities and reliabilities.

\begin{tabular}{cccccccc}
\hline Variable & Items & $\begin{array}{c}\text { FL(Min- } \\
\text { Max) }\end{array}$ & Mean & SD & CSR & e-WOM & Loyalty \\
\hline CSR & 5 & $0.73-0.81$ & 3.97 & 0.41 & $\mathbf{( 0 . 7 7 )}^{\mathbf{x}}$ & $0.28^{* *}$ & $0.22^{* *}$ \\
\hline e-WOM & 3 & $0.76-0.83$ & 4.26 & 0.38 & & $(0.72) \mathrm{x}$ & $0.31^{* *}$ \\
\hline Loyalty & 3 & $0.66-0.89$ & 4.19 & 0.46 & & & $(0.71) \mathrm{x}$ \\
\hline & & AVE & Alpha & CR & Skewness & Kurtosis \\
\hline & & CSR & 0.59 & 0.78 & 0.80 & -0.41 & 0.42 \\
& e-WOM & 0.52 & 0.73 & 0.74 & - & 0.36 \\
& Loyalty & 0.51 & 0.71 & 0.71 & $0.62-0.39$ & 0.49 \\
\hline
\end{tabular}

$\chi 2 / d f=4.23$, RMSEA $=0.056, \mathrm{NFI}=0.935, \mathrm{CFI}=0.941, \mathrm{GFI}=0.937$

Notes: FL: factor loading; Alpha: Cronbach's $\alpha$ coefficient; CR: composite reliability; AVE: average variance extracted. ${ }^{\mathrm{x}}=$ square root of AVE, CSR, corporate social responsibility on social media; e-WOM, electronic word of mouth. ${ }^{* *}=$ significant values.

For example, the value of the correlation between CSR and e-WOM is $0.28^{* *}$ which is positive and significant. Furthermore, the values of standard deviation for all three variables are less than 1 , which indicates that there is less variability in the data. Hence, the data is close to its mean which is a good indication in the context of the overall health of the data. Likewise, the results of convergent and divergent validities are also reported in Table 2. The convergent validity was assessed with the values of average variance extracted (AVE). The rule here is if the value of AVE for a variable is greater than 0.5 , it is an indication that the items of that variable are converging on to it and hence the condition of convergent validity is satisfied. In this regard, all values of AVEs were greater than 0.5 . Therefore, the authors established that the condition of convergent validity is satisfied well.

Next, the authors assessed the discriminant validity, which was calculated by taking the square root of AVE for each variable and comparing it to the values of correlations of other variables. For example, the square root of CSR is $0.77^{* *}$ which is greater than the correlation values $\left(0.28^{* *}, 0.22^{* *}\right)$. All these results revealed that the criterion of discriminant validity is satisfied well. The authors have also reported the results of reliability in Table 2 ( $\alpha$ values, $C R$ values). Both types of reliability values were above the threshold level of 0.7 and hence there was no issue of reliability. Additionally, the authors also performed the data normality test as per the guidelines of Brown [61] who mentioned that the data are normally distributed if Skewness values are between \pm 3 , and Kurtosis values range between \pm 10 which is the case here (see Table 2). Lastly, the result of confirmatory factor analysis has also been reported in the last row of Table 2. The results confirmed that there is a good fit between theoretical model and the database model of the present study $\left.\chi^{2} / d f=4.23, \mathrm{RMSEA}=0.056, \mathrm{NFI}=0.935, \mathrm{CFI}=0.941, \mathrm{GFI}=0.937\right)$.

\subsection{Hypotheses Testing}

In order to validate the hypotheses of the present study, the authors performed the structural equation modeling technique using AMOS software that is an advanced level of co-variance-based data analysis technique, which is helpful to analyze the complex models. The authors in this regard performed the analysis in two steps. In the first step, the authors tested the direct effects without the inclusion of any mediator. The results of direct effect model specified that Hypothesis 1 and Hypothesis $2(\mathrm{H} 1, \mathrm{H} 2)$ of the present study are 
positive and significant (for H1, $\beta=0.233 * *, \mathrm{LLCI}=0.237$, $\mathrm{ULCI}=0.494, p<0.05$; for $\mathrm{H} 2$, $\left.\beta=0.233^{* *}, \mathrm{LLCI}=0.237, \mathrm{ULCI}=0.494, p<0.05\right)$. Hence both $\mathrm{H} 1$ and $\mathrm{H} 2$ are accepted. In the second step, the authors tested for the results of mediation. In this regard, the authors used bootstrapping option in AMOS. The authors selected a larger bootstrap sample of 2000 which AMOS calculates automatically. The results of bootstrapping validated that there is a mediation effect of e-WOM between CSR on social media and consumer loyalty. Furthermore, it was also observed that this mediation was partial in nature as the beta value is reduced from $0.33^{* *}$ to $0.096^{* *}$. Based on all these results, the authors established that all three hypotheses of the present study are true and accepted. The results of hypotheses testing are also presented in Table 3.

Table 3. Results of Hypotheses Testing.

\begin{tabular}{|c|c|c|c|c|c|}
\hline Hypothesis & S.E & LLCI & \multicolumn{2}{|l|}{ ULCI } & Decision \\
\hline & \multicolumn{5}{|c|}{ Model 1: Direct Effects } \\
\hline \multirow{4}{*}{$\begin{array}{l}\text { H1: CSR } \rightarrow \text { loyalty } \\
\text { H2: CSR } \rightarrow \text { e-WOM }\end{array}$} & $0.33^{* *}$ & 0.038 & 0.23 & 0.52 & supported \\
\hline & $0.29^{* *}$ & 0.046 & 0.34 & 0.68 & supported \\
\hline & \multicolumn{5}{|c|}{$\begin{array}{l}(\chi 2 / d f=3.96, \mathrm{RMSEA}=0.051, \mathrm{NFI}=0.943, \mathrm{CFI}=0.949, \mathrm{GFI}=0.943)^{* * *} \\
* * * \\
\text { model fit indices for direct effect model; }\end{array}$} \\
\hline & \multicolumn{5}{|c|}{ Model 2: Indirect Effect (Mediation Model) } \\
\hline \multirow{2}{*}{$\begin{aligned} \text { H3: CSR } \rightarrow \text { e-WOM } & \rightarrow \\
& \rightarrow \\
& \text { Loyalty } \\
& \\
& * * * *\end{aligned}$} & $0.096^{* *}$ & 0.022 & 0.19 & 0.43 & supported \\
\hline & \multicolumn{5}{|c|}{$\begin{array}{l}(\chi 2 / d f=3.11, \mathrm{RMSEA}=0.044, \mathrm{NFI}=0.948, \mathrm{CFI}=0.956, \mathrm{GFI}=0.947){ }^{* * *} \\
\text { model fit indices for mediated (three factor) model; }{ }^{* *} \text { beta value significant }\end{array}$} \\
\hline
\end{tabular}

Notes: CSR, corporate social responsibility on social media; e-WOM, electronic word of mouth; S.E = standard error, LLCI = lower limit confidence interval, ULCI = upper limit confidence interval.

\section{Discussion and Implications}

The present study was conducted to investigate the impact of CSR communication through social media on consumer loyalty with the mediating effect of e-WOM in the banking sector of China. The results of the present study revealed that CSR communication through social media has a direct relation with consumer loyalty. The respondents of the survey confirmed that CSR communication of their banks is influential in building a higher level of loyalty. Furthermore, as a result of CSR communication through social media they are informed of the social responsibility performance of their bank. In this regard, they feel positive when they see their bank is actively involved in different CSR activities. The respondents further confirmed that the emergence of social media has facilitated them with an opportunity to improve their brand decision journey. The consumers on social media, express and share their views with the organization and their social media colleagues. Social media provide them an interactive, fast, and flexible forum of communication through which they not only give their feedback to their bank but also share their brand journey with others. This finding can also be explained with the help of attribution theory. In this connection, the attribution process of consumers helps them in identifying and evaluating a brand meaningfully. Through the attribution process, the consumers are able to mark a bank as a "socially responsible" bank, and hence this process of attribution facilitates them for a positive evaluation of a bank. Hence, the study established that CSR communication through social media is directly related to consumer loyalty. This finding also seeks support from the extant literature $[12,26,58]$. Moreover, the results of the present study also confirmed that e-WOM is a potential mediator between CSR communication of social media and consumer loyalty. The respondents affirmed that through the CSR communication of their bank on social media, they build positive emotions for their bank. They further validated that their positive emotions due to CSR activities of a bank urge them to use positive e-WOM with other colleagues on social media. Hence, all these processes lead the consumers towards a higher level of loyalty. This finding is very important from 
the perspective of the theory of norm reciprocity in the sense that consumers want to reciprocate their bank positively in exchange for their CSR engagement. Hence, in this reciprocal process, they spread positive WOM for the bank on social media. This finding of the present study is in line with the findings of extant researchers who noticed a positive link between CSR and e-WOM [22,37,47].

There are some important theoretical and practical implications of the present study. In this regard, the first theoretical implication of the present study is that it adds to the existing literature of CSR from the perspective of consumer-centric outcomes. Whereas the previous studies have largely explored CSR from an organizational perspective $[17,18,62,63]$. The second theoretical implication of the present study is that it enriches the existing literature of CSR and consumer behavior by introducing e-WOM as a potential mediator in the proposed relationship of CSR and consumer loyalty. There have been different studies in previous literature that confirmed that WOM is very important in shaping consumer purchase preferences $[64,65]$. However, the past studies failed to establish how e-WOM can be a potential mediator between CSR communication through social and consumer loyalty. Lastly, the present study adds to the existing literature of CSR from the perspective of the banking sector. The majority of the previous studies in this regard largely addressed CSR in the context of the manufacturing sector [64,65].

The practical implications of the present study are also important especially for the policymakers from the banking sector of China. In this context, policymakers are encouraged to use the findings of the present study to upgrade their viewpoint towards CSR. They need to realize that well-planned CSR activities of their bank can provide them a solid base to enhance their consumers' loyalty. This is very important for policymakers from the banking sector because earning consumer loyalty in a homogenized sector such as banking is very difficult. But the findings of the present study can provide them new insights about how to build a higher level of consumer loyalty even in a homogenized sector. Likewise, the policymakers are encouraged to use social media activity as the findings of the present study confirmed that through social media, organizations can help their consumers for a meaningful brand decision journey. They need to acknowledge that through social media they can engage their consumers with the brand successfully. In the same vein, policymakers are encouraged to base their business operations close to the philosophy of CSR as the organizations with an image of a "socially responsible" entity are in a better position to grab the attention of consumers as compared to the competitors who do not understand the importance of CSR.

\section{Limitations and Direction for the Future}

The present study is not without limitations. The first limitation of the present study lies in its approach to explain consumer loyalty only from the perspective of CSR. In reality, the behavior of consumers is a complex phenomenon to understand because it is affected by multiple sources. Although the proposed relationships of the variables in the present study were statistically significant, it will be wise for future researchers to include more variables in upcoming studies. The authors propose consumers' pro-environmental behavior, organizational environmental commitment, and open innovation can be included in the model of the present study for a better explanation of consumer behavior. Therefore, future researchers are required to consider these variables along with other variables. Second, the cross-sectional nature of the data limits the ability to predict causality with confidence. In this regard, future researchers are encouraged to use longitudinal data in order to better establish the causality in proposed relations. Lastly, the topic of brand equity is of great interest for researchers and policymakers in the field of marketing. Hence, it will be of great interest for future researchers to investigate if the emotional pull created by organizations through CSR communication on social media is helpful to induce brand equity? Furthermore, what kind of brand equity (consumer-based or finance based) is more affected by CSR will also be interesting for future researchers. 


\section{Conclusions}

To conclude, it is imperative for policymakers, especially from banking institutions, to incorporate sustainability core to their business operations. Because incorporating sustainability is not only concerned with environmental management, but it also brings multiple benefits for an organization. The customers associate themselves positively with an organization that is involved in sustainability practices on real terms, and customers are willing to pay a price premium to such organizations. Likewise, policymakers need to understand the importance of social media to communicate with customers in an effective way and to engage them with the organization for brand image development purposes. Customers on social media share sustainability interventions of an organization with their social media colleagues and hence positive e-WOM for a brand is established. In like manner, customers' sustainability communication of an organization on social media is a key touch-point for increasing their loyalty to a specific brand. In a nutshell, customer-related CSR activities on social media are concerned with positive behavioral outcomes (loyalty in this case) which are very important for an organization in the context of marketing-related objectives.

Author Contributions: All of the authors contributed to conceptualization, formal analysis, investigation, methodology and writing and editing the original draft. All authors have read and agreed to the published version of the manuscript.

Funding: This research received no external funding.

Informed Consent Statement: Informed consent was obtained from the respondent of the survey.

Data Availability Statement: The data will be made available on request from the corresponding author.

Conflicts of Interest: The authors declare no conflict of interest.

Ethics Statement: This study was carried out in accordance with the recommendations of the Academic Ethical Review Board of the Wuhan University of Technology, Hubei, China. The protocol was approved by the Academic Ethical Review Board and Graduate School of the Wuhan University of Technology, China. All subjects participating in this research gave their written informed consent in accordance with the Declaration of Helsinki, and were informed there was no knowing or anticipated risks associated with the participation in this research study, and reminded of their right that they may refuse to take part in the study or withdraw from the study at any time without jeopardizing their employment or any other rights before the survey. Prior to submission this manuscript has been reviewed and approved in its final form by the Academic Ethical Review Board of Wuhan University of Technology.

\section{Appendix A}

Table A1. The questionnaire items.

\begin{tabular}{ll}
\hline \multicolumn{1}{c}{ Construct } & \multicolumn{1}{c}{ Items } \\
\hline CSR & This bank is a socially responsible bank. \\
& This banks is more beneficial to society's welfare than other banks. \\
& This bank contributes to society in positive ways. \\
& I Share this bank' (CSR) posts on my own Facebook page. \\
& I engage in conversations (CSR) on social media page(s) of this bank. \\
& I am likely to spread positive word of mouth about (this bank) on social media. \\
e-WOM & I would recommend (this bank) products/services to my friends on social media. \\
& If my friends were looking to purchase banking services, I would tell them to try [this bank] \\
& on social media. \\
Loyalty & I consider this bank my first choice when I purchase the services they supply. \\
& I am willing to maintain my relationship with this bank. \\
& I am loyal to this bank. \\
\hline
\end{tabular}




\section{References}

1. Vithayathil, J.; Dadgar, M.; Osiri, J.K. Social media use and consumer shopping preferences. Int. J. Inf. Manag. 2020, 54, 102117. [CrossRef]

2. Kemp, S. Digital 2020: 3.8 Billion People Use Social Media. Available online: https://wearesocial.com/blog/2020/01/digital-20 20-3-8-billion-people-use-social-media (accessed on 21 January 2021).

3. Dean, B. Social Network Usage \& Growth Statistics: How Many People Use Social Media in 2021? Available online: https: / / backlinko.com/social-media-users (accessed on 4 February 2021).

4. Briciu, V.-A.; Briciu, A. Social Media and Organizational Communication. In Encyclopedia of Organizational Knowledge, Administration, and Technology; IGI Global: California, USA, 2021; pp. 2609-2624. Available online: https://www.igi-global.com/chapter/ social-media-and-organizational-communication/263715 (accessed on 4 February 2021).

5. Gil, S. The 9 Best Brands On Social Media. Available online: https:/ / eclincher.com/the-9-best-brands-on-social-media / (accessed on 3 February 2021).

6. Damian, T. In the New Robopolitics, Social Media Has Left Newspapers for Dead. Available online: http://www.theguardian. com/commentisfree/2016/nov/18/robopolitics-social-media-traditional-media-dead-brexit-trump (accessed on 5 February 2021).

7. Carroll, A.B.; Laasch, O. From managerial responsibility to CSR and back to responsible management. In Research Handbook of Responsible Management; Edward Elgar Publishing: Cheltenham, UK, 2020.

8. Bowen, H.R.; Johnson, F.E. Social Responsibility of the Businessman; Harper: New York, NY, USA, 1953.

9. Kamal, Y. Stakeholders expectations for CSR-related corporate governance disclosure: Evidence from a developing country. Asian Rev. Account. 2021. [CrossRef]

10. Troise, C.; Camilleri, M.A. The use of digital media for marketing, CSR communication and stakeholder engagement. In Strategic Corporate Communication in the Digital Age; Camilleri, M.A., Ed.; Emerald Publishing Limited: Bingley, UK, 2021. [CrossRef]

11. Kapoor, P.S.; Balaji, M.; Jiang, Y. Effectiveness of sustainability communication on social media: Role of message appeal and message source. Int. J. Contemp. Hosp. Manag. 2021. [CrossRef]

12. Ahmad, N.; Naveed, R.T.; Scholz, M.; Irfan, M.; Usman, M.; Ahmad, I. CSR Communication through Social Media: A Litmus Test for Banking Consumers' Loyalty. Sustainability 2021, 13, 2319. [CrossRef]

13. Gomez, L.M. The State of Social Media Research in CSR Communication; Seifi, S., Crowther, D., Eds.; Palgrave Macmillan: Cham, Switzerland, 2020. [CrossRef]

14. Tamvada, M. Corporate social responsibility and accountability: A new theoretical foundation for regulating CSR. Int. J. Corp. Soc. Responsib. 2020, 5, 1-14. [CrossRef]

15. Ahmad, N.; Ullah, Z.; Mahmood, A.; Ariza-Montes, A.; Vega-Muñoz, A.; Han, H.; Scholz, M. Corporate Social Responsibility at the Micro-Level as a "New Organizational Value" for Sustainability: Are Females More Aligned Towards It? Int. J. Environ. Res. Public Health 2021, 18, 2165. [CrossRef] [PubMed]

16. Singh, K.; Misra, M. Linking Corporate Social Responsibility (CSR) and Organizational Performance: The moderating effect of corporate reputation. Eur. Res. Manag. Bus. Econ. 2021, 27, 100139. [CrossRef]

17. Franco, S.; Caroli, M.G.; Cappa, F.; Del Chiappa, G. Are you good enough? CSR, quality management and corporate financial performance in the hospitality industry. Int. J. Hosp. Manag. 2020, 88, 102395. [CrossRef]

18. Kim, B.-J.; Nurunnabi, M.; Kim, T.-H.; Jung, S.-Y. The influence of corporate social responsibility on organizational commitment: The sequential mediating effect of meaningfulness of work and perceived organizational support. Sustainability 2018, 10, 2208. [CrossRef]

19. Gao, Y.; He, W. Corporate social responsibility and employee organizational citizenship behavior. Manag. Decis. 2017, 55, 294-309. [CrossRef]

20. Kong, L.; Sial, M.S.; Ahmad, N.; Sehleanu, M.; Li, Z.; Zia-Ud-Din, M.; Badulescu, D. CSR as a Potential Motivator to Shape Employees' View towards Nature for a Sustainable Workplace Environment. Sustainability 2021, 13, 1499. [CrossRef]

21. Han, H.; Al-Ansi, A.; Chi, X.; Baek, H.; Lee, K.-S. Impact of environmental CSR, service quality, emotional attachment, and price perception on word-of-mouth for full-service airlines. Sustainability 2020, 12, 3974. [CrossRef]

22. Fatma, M.; Ruiz, A.P.; Khan, I.; Rahman, Z. The effect of CSR engagement on eWOM on social media. Int. J. Organ. Anal. 2020, 28, 941-956. [CrossRef]

23. Aramburu, I.A.; Pescador, I.G. The effects of corporate social responsibility on customer loyalty: The mediating effect of reputation in cooperative banks versus commercial banks in the Basque country. J. Bus. Ethics 2019, 154, 701-719. [CrossRef]

24. Bediako, B.; The Impact of Corporate Social Responsibility on Customer Loyalty. A Case Study of StanBed Tours ky. 2017. Available online: https:/ / www.theseus.fi (accessed on 11 January 2021).

25. Gill, M.B.; Jensen, K.L.; Lambert, D.M.; Upendram, S.; English, B.C.; Labbé, N.; Jackson, S.W.; Menard, R.J. Consumer preferences for eco-friendly attributes in disposable dinnerware. Resour. Conserv. Recycl. 2020, 161, 104965. [CrossRef]

26. Sun, H.; Rabbani, M.R.; Ahmad, N.; Sial, M.S.; Cheng, G.; Zia-Ud-Din, M.; Fu, Q. CSR, Co-Creation and Green Consumer Loyalty: Are Green Banking Initiatives Important? A Moderated Mediation Approach from an Emerging Economy. Sustainability 2020, 12, 10688. [CrossRef]

27. Fusva, A.; Dean, D.; Suhartanto, D.; Syarief, M.E.; Arifin, A.Z.; Suhaeni, T.; Rafdinal, W. Loyalty formation and its impact on financial performance of Islamic banks-evidence from Indonesia. J. Islamic Mark. 2020. [CrossRef] 
28. Khan, M.S.; Saengon, P.; Alganad, A.M.N.; Chongcharoen, D.; Farrukh, M. Consumer green behaviour: An approach towards environmental sustainability. Sustain. Dev. 2020, 28, 1168-1180. [CrossRef]

29. Bigne, E.; Andreu, L.; Perez, C.; Ruiz, C. Brand love is all around: Loyalty behaviour, active and passive social media users. Curr. Issues Tour. 2020, 23, 1613-1630. [CrossRef]

30. Bialkova, S.; Te Paske, S. Campaign participation, spreading electronic word of mouth, purchase: How to optimise corporate social responsibility, CSR, effectiveness via social media? Eur. J. Manag. Bus. Econ. 2020, 30, 108-126. [CrossRef]

31. Fritz, H. The Psychology of Interpersonal Relations; John Wiley and Sons: New York, NY, USA, 1958.

32. Gouldner, A.W. The norm of reciprocity: A preliminary statement. Am. Sociol. Rev. 1960, 25, 161-178. [CrossRef]

33. Chakraborty, U.; Bhat, S. The effects of credible online reviews on brand equity dimensions and its consequence on consumer behavior. J. Promot. Manag. 2018, 24, 57-82. [CrossRef]

34. Jackson, M. Utilizing attribution theory to develop new insights into tourism experiences. J. Hosp. Tour. Manag. 2019, 38, 176-183. [CrossRef]

35. Sharma, T. What a Waste: Confronting Consumer Food Waste Behavior in Hospitality Settings. In Advances in Hospitality and Leisure, Chen, J.S., Ed; Emerald Publishing Limited: Bingley, UK, 2021; Volume 16.

36. Nielsen. Consumer Trust in Online, Social and Mobile Advertising Grows. Available online: http://www.nielsen.com/us/en/ insights / article/2012/consumer-trust-in-online-social-and-mobile-advertising-grows / (accessed on 9 February 2021).

37. Seo, E.J.; Park, J.-W.; Choi, Y.J. The effect of social media usage characteristics on e-WOM, trust, and brand equity: Focusing on users of airline social media. Sustainability 2020, 12, 1691. [CrossRef]

38. De Matos, C.A.; Rossi, C.A.V. Word-of-mouth communications in marketing: A meta-analytic review of the antecedents and moderators. J. Acad. Mark. Sci. 2008, 36, 578-596. [CrossRef]

39. Iyer, R.; Griffin, M. Modeling word-of-mouth usage: A replication. J. Bus. Res. 2021, 126, 512-523. [CrossRef]

40. Yuan, B.; Peluso, A.M. The Influence of Word-Of-Mouth Referral on Consumers' Purchase Intention: Experimental Evidence from WeChat. Sustainability 2021, 13, 645. [CrossRef]

41. Makrides, A.; Vrontis, D.; Christofi, M. An Empirical Study on the Importance of Electronic Word of Mouth in the Concierge Industry: The Case of Cyprus. In Exploring the Power of Electronic Word-of-Mouth in the Services Industry; IGI Global: Hershey, PA, USA, 2020; pp. 265-287. [CrossRef]

42. Chen, Z.; Yuan, M. Psychology of word of mouth marketing. Curr. Opin. Psychol. 2020, 31, 7-10. [CrossRef]

43. Septianto, F.; Chiew, T.M. The effects of different, discrete positive emotions on electronic word-of-mouth. J. Retail. Consum. Serv. 2018, 44, 1-10. [CrossRef]

44. Prasad, S.; Gupta, I.C.; Totala, N.K. Social media usage, electronic word of mouth and purchase-decision involvement. Asia-Pac. J. Bus. Adm. 2017, 9, 134-145. [CrossRef]

45. Bellman, S.; Lohse, G.L.; Johnson, E.J. Predictors of online buying behavior. Commun. ACM 1999, 42, 32-38. [CrossRef]

46. Smith, M.D.; Bailey, J.; Brynjolfsson, E. Understanding Digital Markets: Review and Assessment; MIT Press: Cambridge, UK, 1999.

47. Demirbaş, E. An overview on traditional and electronic word of mouth communication (WOM). Lectio Socialis 2018, 2, 16-26.

48. Wrigley, C.; Straker, K. Affected: Emotionally Engaging Customers in the Digital Age; John Wiley \& Sons: Hoboken, NJ, USA, 2019.

49. Jalilvand, M.R.; Vosta, L.N.; Mahyari, H.K.; Pool, J.K. Social responsibility influence on customer trust in hotels: Mediating effects of reputation and word-of-mouth. Tour. Rev. 2017, 72, 1-14. [CrossRef]

50. Schaefer, S.D.; Terlutter, R.; Diehl, S. Talking about CSR matters: Employees' perception of and reaction to their company's CSR communication in four different CSR domains. Int. J. Advert. 2020, 39, 191-212. [CrossRef]

51. Pang, A.; Lwin, M.O.; Ng, C.S.-M.; Ong, Y.-K.; Chau, S.R.W.-C.; Yeow, K.P.-S. Utilization of CSR to build organizations' corporate image in Asia: Need for an integrative approach. Asian J. Commun. 2018, 28, 335-359. [CrossRef]

52. Hur, W.M.; Kim, H.; Kim, H.K. Does customer engagement in corporate social responsibility initiatives lead to customer citizenship behaviour? The mediating roles of customer-company identification and affective commitment. Corp. Soc. Responsib. Environ. Manag. 2018, 25, 1258-1269. [CrossRef]

53. Markovic, S.; Iglesias, O.; Singh, J.J.; Sierra, V. How does the perceived ethicality of corporate services brands influence loyalty and positive word-of-mouth? Analyzing the roles of empathy, affective commitment, and perceived quality. J. Bus. Ethics 2018, 148, 721-740. [CrossRef]

54. van Asperen, M.; de Rooij, P.; Dijkmans, C. Engagement-based loyalty: The effects of social media engagement on customer loyalty in the travel industry. Int. J. Hosp. Tour. Adm. 2018, 19, 78-94. [CrossRef]

55. Eisingerich, A.B.; Rubera, G.; Seifert, M.; Bhardwaj, G. Doing good and doing better despite negative information?: The role of corporate social responsibility in consumer resistance to negative information. J. Serv. Res. 2011, 14, 60-75. [CrossRef]

56. Kang, J.; Hustvedt, G. Building trust between consumers and corporations: The role of consumer perceptions of transparency and social responsibility. J. Bus. Ethics 2014, 125, 253-265. [CrossRef]

57. Dagger Tracey, S.; David Meredith, E.; Ng, S. Do relationship benefits and maintenance drive commitment and loyalty? J. Serv. Mark. 2011, 25, 273-281. [CrossRef]

58. Raza, A.; Saeed, A.; Iqbal, M.K.; Saeed, U.; Sadiq, I.; Faraz, N.A. Linking corporate social responsibility to customer loyalty through co-creation and customer company identification: Exploring sequential mediation mechanism. Sustainability 2020, 12, 2525. [CrossRef]

59. Harman, H.H. Modern Factor Analysis; University of Chicago Press: Chicago, IL, USA, 1976. 
60. Hair, J.F.; Anderson, R.E.; Tatham, R.L.; Black, W.C. Multivariate data Analysis; Prentice Hall: Englewood Cliff, NJ, USA, 1998; Volume 5, pp. 207-2019.

61. Brown, T.A. Confirmatory Factor Analysis for Applied Research; Guilford Publications: New York, NY, USA, 2015.

62. Ramzan, M.; Amin, M.; Abbas, M. How does corporate social responsibility affect financial performance, financial stability, and financial inclusion in the banking sector? Evidence from Pakistan. Res. Int. Bus. Financ. 2021, 55, 101314. [CrossRef]

63. Sarkar, S.; Chatterjee, M.; Bhattacharjee, T. Does CSR disclosure enhance corporate brand performance in emerging economy? Evidence from India. J. Indian Bus. Res. 2021. [CrossRef]

64. Bux, H.; Zhang, Z.; Ahmad, N. Promoting sustainability through corporate social responsibility implementation in the manufacturing industry: An empirical analysis of barriers using the ISM-MICMAC approach. Corp. Soc. Responsib. Environ. Manag. 2020, 27, 1729-1748. [CrossRef]

65. Chen, L.; Feldmann, A.; Tang, O. The relationship between disclosures of corporate social performance and financial performance: Evidences from GRI reports in manufacturing industry. Int. J. Prod. Econ. 2015, 170, 445-456. [CrossRef] 